\title{
Coercion, Competition and Communication: Different Approaches of European Governance and their Impact on National Institutions
}

\author{
CHRISTOPH KNILL \\ Friedrich Schiller Universität Jena \\ ANDREA LENSCHOW \\ University of Osnabrück
}

\begin{abstract}
This analysis focuses on the relationship between supranational regulatory policy and national administrative change. We argue that the potential for change and cross-national convergence varies with the particular governance pattern employed, namely coercion, competition and communication. We identify the behavioural rationalities that guide the national bureaucratic responses and point to certain paradoxes with regard to the extent and direction of change.
\end{abstract}

\section{Introduction}

The European Union (EU) governance system has centralized a great extent of regulatory policy-making in Brussels, but relies heavily on national administrative actors to put European rules into practice. ${ }^{1}$ Implementation studies show that we cannot assume this to be a smooth process. National bureaucracies are

\footnotetext{
${ }^{1}$ This can be traced to the fact that the execution of Community policies is typically left to national administrations, notwithstanding the existence of 16 agencies currently at the EU level which cover a broad range of different tasks (Majone, 1996; Flinders, 2004, p. 524). Of these agencies only few can be classified as management agencies, however, executing European policies on behalf of the Commission (such as the European Training Foundation). Most of the European agencies have no executive competences. They fall within the category either of information agencies whose main function is to gather information and to liaise between national authorities and EU administrations, or regulatory agencies entrusted with the duty of rule-making in highly specialized areas such as trademarks or plant variety rights (Dehousse, 1997; Chiti, 2003). The impact of regulatory agencies on domestic administrations is, therefore, very similar to the domestic effects emerging from the implementation of EU policies, namely what we classify as coercive governance in this article. In contrast, the domestic effects of information agencies follow our communicative mode, given their important role in establishing and promoting networks of information exchange between national administrations.
} 
frequently referred to as the 'bad guys' who are either incapable of engaging in the necessary changes, or are unwilling to do so. Considering, however, that on the path of European integration we have witnessed massive restructuring and reforms at the national level, we need to adopt a more differentiated perspective. In this article we attempt to reflect on the behavioural rationalities of national bureaucracies by distinguishing between various forms of regulatory policy-making in the EU. We trace potentially different patterns of bureaucratic adaptation with respect to structures, standard operating procedures and their role in the national political system and in relation to society.

The link between EU rule-making and national bureaucratic response is crucial to understanding patterns and performance of EU governance. The dominant form of EU policy-making is the regulatory intervention in national markets and state-society relations (Majone, 1996). Regulatory policy typically places bureaucracies at centre stage as actors responsible for implementation in a formal sense as the developers of the administrative framework necessary for ensuring compliance with EU rules and standards on the part of both 'street level bureaucrats' and those private actors addressed in a practical sense as the actual executors of those rules that are directed at the state.

National bureaucracies are to a remarkable extent already involved in the formulation of EU policy-making. Nevertheless, EU policy frequently poses challenges of adaptation to national actors, triggering many different responses as the literature on 'Europeanization' and 'multilevel governance' has emphasized. The literature on multilevel governance (cf. Marks et al., 1996; Bache and Flinders, 2004) addresses changes in the distribution of competences and power between the European, national and sub-national levels. Europeanization studies are primarily interested in the effects of European institutions, processes and policies on corresponding arrangements in the Member States (see, e.g., Cowles et al., 2001; Héritier et al., 2001; Knill, 2001). In contrast to this literature, which - besides dealing with the nature of the European political system - highlights national institutions and circumstances as explanatory factors for variance across Member States, we aim in this article to develop some hypothetical statements about the link between different EU governance patterns and the likelihood of far-reaching national change and cross-national convergence of regulatory styles and structures.

We argue that the potential for national institutional change and crossnational convergence varies with the particular governance pattern embedded in EU regulatory policy and distinguish between three such patterns: coercion implied in EU rules and imposed on national implementers; competition between national administrative systems to achieve EU requirements; and communication between regulatory agents across national levels arranged in a EU legal or institutional framework. We will point to certain paradoxical 
patterns in the responses of national bureaucracies exposed to these forms of regulatory policy-making in the EU.

This article proceeds as follows: in a first step we elaborate on the three governance patterns and develop some hypotheses on national institutional change and cross-national convergence. We base these hypotheses on certain rationalities which we believe characterize the bureaucratic responses to the EU governance approach. We treat these rationalities as theoretical assumptions in this abstract part of the article. The second part turns to empirical material for illustration of an abstract argument. In the conclusion we highlight trends as well as open questions, setting the stage for future systematic research. We also embed our discussion in the wider discourse on EU governance and the future of national institutional structures in the multi-level system of the Union.

\section{Three Governance Patterns of EU Regulatory Policy}

The EU's pursuit of setting up a common market is characterized by different modes of steering the relevant actors toward desired behaviour. The particular steering modes that may be chosen imply different institutional prerequisites and, hence, pose demands or incentives for institutional adaptation. Notwithstanding national differences, we argue that the national bureaucracies, as the main addressees of these demands and incentives, tend to follow certain general rationalities in responding to these inputs, making institutional change and cross-national convergence more or less probable.

\section{Coercion}

The functioning of the European common market depends on the existence of certain shared rules and standards to develop a stable and reliable framework for producers and consumers moving freely across European borders, and to level the playing field between these actors. Many such rules relate to the removal of barriers to trade; but they also constitute agreements of common constraints for economic actors in order to protect workers, consumers, the environment or cultural heritage. Especially in the latter cases we see a dominance of coercive governance, defined as legally binding European legislation which leaves little or no discretion to the national implementer.

At first sight the concept of coercion may seem curious considering that such regulation depends on Member States agreeing to them and their binding, coercive force. Dolowitz and Marsh have coined this feature of EU policymaking the 'negotiated transfer' (2000, p. 15) of rules with a sanctioning potential. Various factors explain why most of these 'transfers' imply a departure from the policy status quo at the national level. These range from the uniform character of the norms or standards, increasingly flexible decision rules and 
practices, the inability of national policy-makers sometimes to comprehend fully the reform implications or the desire to choose the European route to push policy reforms which might fail domestically. Regardless of the specific dynamic shaping the decision-making, we have witnessed the rise of tough policy requirements putting many Member States and their implementing agencies under considerable compliance pressure.

Interesting from the perspective adopted in this article is the link between policy compliance and institutional change. Coercive regulatory policies are prone to having institutional impacts as frequently procedural obligations are defined and organizational structures presupposed in EU legislation. For instance, a regulation may call for the creation of new organizations (e.g. regulatory agencies), the centralization of regulatory processes (e.g. imposing reporting requirements on a central authority), or demand horizontal organizational change (e.g. requiring the co-ordination of previously distinct administrative tasks). Furthermore, European legislation may impact on national administrative styles, including patterns of state intervention (e.g. the degree of hierarchical imposition), as well as administrative interest mediation (e.g. the degree of formalization) (Knill and Lenschow, 1998). In short, EU policy often assumes a given administrative model with the effect that national bureaucracies face a double challenge of adaptation.

What is the typical rationality of national bureaucracies in reacting to this challenge? We suggest that the prevailing response is indeed persistencedriven, meaning that bureaucracies attempt to meet the policy obligations while minimizing their institutional adaptation cost. In the context of coercive governance, national bureaucracies remain widely autonomous in finding appropriate ways towards policy compliance. The coercive mode focuses on formal and timely compliance with EU standards, not explicitly valuing the search for most efficient and effective paths towards solving a given problem. Hence, it keeps the bureaucracies insulated from outside pressure to engage in extensive administrative optimization efforts. Consequently, national adjustments will primarily follow the pattern of administrative self-adaptation. Both the literature on bureaucratic politics and that on organizational behaviour more generally suggest that this administrative rationality typically coincides with rather incremental and gradual adjustments of established routines and procedures (March and Olsen, 1989). Given the strong emphasis placed on institutional maintenance and continuity, change is likely to be limited to adaptation that is unavoidable in the light of the policy requirements defined in the EU legislation.

Two hypotheses follow: we expect, firstly, a minimalist approach to institutional change in response to coercive forms of governance in the EU; and, secondly, due to this relative persistence of national institutional structures 
very little convergence of institutional structures between the Member States. These hypotheses point to a paradox considering that the main objective of coercive forms of governance in EU regulatory policy is a high level of harmonization across states and given the close link between policy compliance and institutional design. While national policy-makers have a high incentive to harmonize the rules and procedures governing the common market, national bureaucracies counter with an incentive to protect traditional structures. This tension remains unresolved given the high autonomy of national bureaucracies in complying with 'top-down' coercive EU legislation. Only outright non-compliance with EU policy will subject national bureaucracies to external judicial but also societal pressure - a threat too remote to contemplate radical institutional change from the start.

\section{Competition}

The influence of EU regulatory policy on national institutions is less direct in the case of governance by competition. This approach implies only limited legally-binding requirements for domestic institutional change. Rather its main purpose is to promote and stimulate the optimization of institutional arrangements in the Member States within a general framework set at the EU level. Pressure for institutional adjustment thus basically emerges from the need to rearrange and redesign national arrangements in order to enhance their effectiveness in achieving certain, politically-defined objectives (such as an increase in foreign direct investment or the reduction of unemployment) in comparison to the performance of other Member States (Oates and Schwab, 1988). Whilst European policies thus pose potential challenges for domestic institutions, they do not prescribe any distinctive institutional model of how the new institutional equilibrium should actually look, but leave the Member States broad discretion in institutional design. Their coercive impact is confined to the definition of legally-binding 'rules of the game' with which Member States have to comply (Knill and Lehmkuhl, 2002).

What is the rationality underlying institutional change in such constellations? Change is now based on the need to improve the functional effectiveness of institutional arrangements in comparison to the performance of those arrangements in other Member States. Rather than securing institutional persistence (regardless of performance questions), the basic focus is on effects such as the impact, for instance, of certain regulatory arrangements on the competitive position of the national industry within the common market.

The performance-driven rationality behind institutional change is hence rooted in systems' competition. Competition implies that there will be winners and losers, that is, redistributional effects, between and within Member States depending on the comparative performance of national regulatory 
practices and institutions. Different national systems of taxation, for instance, might result in enormous moves of capital and investment between countries, with wider consequences on national tax revenues, economic performance or employment rates.

The bureaucracy now is no longer in an autonomous position when adjusting national institutions to European requirements. Given the far-reaching performance consequences of different institutional designs, there is a growing potential for societal mobilization and politicization in favour of institutional change. Bureaucratic self-interest in ensuring institutional persistence can be overturned by political and societal mobilization and is highly contingent on the preferences of and struggle between political leaders. The role of the bureaucracy in institutional reform will thus be more instrumental than autonomous (Knill, 2001). There is a higher potential that the bureaucracy is deliberately transformed 'from outside' (Knight, 1992).

Which hypotheses regarding institutional change and cross-national convergence follow from these considerations? First, we expect that there is higher potential for fundamental and path-breaking reforms as the persistence-driven 'reflex' of the bureaucracy is constrained. Of course, this does not preclude periods of incremental forms of bureaucratic self-adaptation and institutional persistence, especially as long as the competitive performance of existing institutions remains at a satisfactory level. However, as soon as potential gains or losses become politicized, decisions about form and scope of institutional change will be 'up for grabs'.

As regards the cross-national convergence of institutions, we expect that EU governance by regulatory competition will result in growing institutional similarity of national regulatory styles and structures over time. In contrast to economic theories of regulatory competition claiming that countries move their levels of regulation towards equilibrium (Holzinger and Knill, 2004), we do not expect there to be full institutional convergence at the end of the process. Existing institutional traditions form a context for institutional performance and there may be no single functional optimum of regulatory styles and structures to which all countries will converge (March and Olsen, 1989). Notwithstanding institutional path-dependency, the fundamental challenges emerging from systems' competition is likely to reduce the variance between different national arrangements. In line with institutional arguments, we expect the strongest convergence between countries characterized by similar state, legal and administrative traditions and possibly the emergence of several functionally equivalent models to which groups of countries converge. This leads us to the paradoxical conclusion that European governance by competition, which explicitly allows for domestic diversity, has a stronger convergence potential 
on domestic institutions than policies that seek to trigger this effect in a more explicit way such as coercive regulation.

\section{Communication}

A third type of governance targets national institutions by way of communication and information exchange in transnational networks. At the heart of this approach are two objectives: the stimulation of information exchange and mutual learning between national policy-makers and the development and promotion of innovative regulatory models or concepts - 'best practice' - to be applied in the Member States. There is no legally-binding prescription of institutional models for domestic compliance; rather, these models offer non-binding suggestions for national policy-makers to guide the search for regulatory solutions to certain policy problems (Knill and Lehmkuhl, 2002).

This governance approach, which is currently diffusing from international organizations such as the OECD into the EU repertoire, is thus characterized by its voluntary nature and a high degree of openness as policy suggestions leave broad leeway for interpretation and adjustment to domestic conditions. Moreover, the promotion of certain concepts, which have been successfully applied in other countries, is based on policy transfer (Dolowitz and Marsh, 2000) rather than competitive selection. The underlying idea is to stimulate cross-national lesson-drawing (Rose, 1991) and learning through comparing and evaluating the performance of different national approaches (Tews, 2002, p. 174).

Institutional change, we suggest, now follows the rationale of securing and increasing the legitimacy of certain institutional arrangements within a transnational discourse. National policy-makers and bureaucratic elites compete for 'authorship' of or at least adherence to leading models in order to legitimize their very existence. In this context, institutional actors typically embrace forms and practices which are widely accepted and valued within the 'myths' of the broader institutional environment (DiMaggio and Powell, 1991). Striving for legitimacy is analytically distinct from the persistence- or performance-driven rationalities: it is a response to dominant discourses rather than the minimization of change. If necessary, flexible and far-reaching reforms of existing arrangements secure the survival of the institution. The bureaucratic interest to protect the institution is pursued, not defensively by prioritizing the status $q u o$, but responsively through dynamic adjustment. Moreover, not so much the functionality but transnational acceptance of the institutional design guide this dynamic.

What explains such legitimacy-driven rationality in the face of governance based on communication and information exchange in transnational networks? The embeddedness of national bureaucrats and policy-makers in transnational 
expert networks implies not only that these actors can observe and learn from developments in other countries, but also that they are 'observed' by their counterparts; i.e. they have to demonstrate the quality and legitimacy of their concepts vis-à-vis external actors. Nationally autonomous bureaucracies may well be tempted to protect national practices and structures and act in a persistence-driven way, but their integration into transnational networks forces them to react to - and survive in - its discourse. Institutional change is thus driven by a bureaucracy confronted with the need to legitimize national developments in the light of 'transnational scrutiny'.

The higher the number of countries adopting a certain approach, the more likely it becomes that the search for legitimacy results in domestic institutional adjustment (Meyer and Rowan, 1977; Meyer et al., 1997). Furthermore, constellations of high uncertainty (DiMaggio and Powell, 1991, p. 70), the existence of time pressures (Bennett, 1991, p. 223), or the attempt to avoid high costs of information (Tews, 2002, p. 180) are likely to incite national institutions to follow the mainstream. Therefore, we expect a moderate and potentially even high degree of institutional change, depending on the presence of a leading model and corresponding pressure to 'move closer'. Moreover, we hypothesize that transnational communication and information exchange carry a high potential of fostering cross-national convergence of regulatory styles and structures, in particular in those constellations identified above. Interestingly, once again convergence of national institutions constitutes a plausible outcome despite the absence of any explicit harmonization pressure.

\section{Empirical Illustration}

In this section, we use examples from different areas of EU regulatory policy (environment, transport and social policy) and OECD regulatory guidance

Table 1: European Governance and National Institutional Change

\begin{tabular}{llll}
\hline $\begin{array}{l}\text { Governance } \\
\text { Pattern }\end{array}$ & \multicolumn{1}{c}{$\begin{array}{c}\text { 'Rationality' of } \\
\text { Adjustment }\end{array}$} & $\begin{array}{c}\text { Institutional } \\
\text { Change }\end{array}$ & $\begin{array}{c}\text { Cross-national } \\
\text { Convergence }\end{array}$ \\
\hline Coercion & $\begin{array}{l}\text { Persistence-driven } \\
\text { (minimize bureaucratic change) }\end{array}$ & Low & Low \\
Competition & $\begin{array}{l}\text { Performance-driven } \\
\text { (optimize outcomes and impacts) }\end{array}$ & High & High \\
Communication & $\begin{array}{l}\text { Legitimacy-driven } \\
\text { (justify national arrangements) }\end{array}$ & Moderate & Moderate to high \\
\hline
\end{tabular}


(environment) to illustrate our theoretical propositions. This section does not represent systematic empirical testing of the hypotheses developed above, but is rather conceived as a plausibility test and illustration.

\section{The Coercive Impact of EU Governance: Environmental Policy}

Governance by coercion is particularly, albeit not exclusively, pronounced in policies of so-called positive integration, including environmental and consumer protection as well as social regulation (Knill and Lehmkuhl, 2002). Community policies are directed at replacing existing domestic regulatory arrangements. In many instances, European policies define highly specified and legally binding requirements implying detailed prescriptions for the adjustment of national regulatory styles and structures and requiring a real re-shaping and re-forming of existing domestic institutions (Scharpf, 1999).

Coercive Nature of Environmental Policy. Although other governance approaches emphasizing voluntariness and discretion for domestic compliance have gained importance since the early 1990s, in EU environmental policy we still observe a clear dominance of the coercive, command-and-control approach. The close link between coercive policy contents and predetermined institutional arrangements for domestic application can be shown for many environmental measures of the EU.

A case in point is the 1980 drinking water directive. The directive specifies quality standards for water intended for human consumption. These standards apply to a range of substances that may pose a threat to human health when present at certain levels of concentration in the water. The substantive standards are not negotiable and apply uniformly to all water providers. In view of these detailed specifications, national regulatory authorities have limited discretion and flexibility in implementing European legislation. More importantly, the prescription of uniform and legally-binding standards assumes hierarchical structures of intervention and quite formal and legalistic patterns of administrative interest intermediation at the domestic level.

In the growing field of EU procedural environmental law the domestic institutional implications are even more evident. The directive on the freedom of access to environmental information (information directive) may serve as an example. This directive aims to ensure free access to information on the environment held by public authorities. It lays down the detailed conditions for making such information accessible, including appeals procedures against refusal or failure to provide information, charges for the provision of information and exemptions from disclosure (Winter, 1996). These detailed procedural prescriptions especially affect national patterns of administrative interest intermediation, namely by demanding a more open and transparent style of environ- 
mental regulation with different societal interests having equal opportunities to access administrative decision-making. They significantly reduce the scope for secretive and closed interaction patterns between regulatory authorities and the regulated industry, as can be observed in many Member States.

Similarly demanding institutional effects flow from the 1985 environmental impact assessment (EIA) directive, which obliges developers of specified kinds of public and private projects to provide information on the environmental impact of these projects to a designated public authority. This environmental impact assessment must then be taken into consideration by those public authorities responsible for the authorization of the project(s) in question. Adequate implementation of this directive implies the concentration or horizontal integration of administrative control responsibilities. Since an impact assessment will deal with the project's implications for air, water and soil pollution as well as potential threats to flora, fauna and human health, the designated public authority ought to be able to evaluate these impacts in a comprehensive way.

Although these measures cover only a small part of the environmental acquis, this small sample makes evident the close link between policy content and corresponding institutional arrangements for domestic implementation, which are implicitly prescribed in European legislation and to which regulatory practice at the domestic level must be adjusted.

Rationality of Institutional Change. Comparative studies on the implementation of EU environmental policy (Knill and Lenschow, 1998; Knill, 2001) back our hypothesis that the adjustment of national institutions is indeed characterized by a persistence-driven pattern of bureaucratic self-adaptation. The central objective of the bureaucracy is to comply with EU legislation while minimizing changes to existing regulatory styles and structures.

For instance, the German administration resisted the adoption of the integrated approach in meeting the requirements of the EIA directive, and merely implemented EIAs in existing authorization procedures, avoiding an overhaul of administrative structures. As a consequence, the German authorization practice remains based on a single-media approach. A similar pattern can be observed in Britain and France, where the EIA was merely integrated into local planning procedures without improving co-ordination between authorities with different control responsibilities. Nowhere is environmental impact given more priority than other considerations in the planning process, as is required by the directive.

Similar patterns characterize the implementation of the information directive. The directive's approach of open and transparent administrative interest intermediation was not compatible with the more closed German practice 
where access to environmental information is generally restricted to parties directly affected by and involved in administrative activities and procedures (Winter, 1996). To avoid changes in existing practices, both the formal and practical implementation were characterized by a narrow interpretation of European policy requirements. Germany's transposition of the directive limited the number of the administrative actors affected, as well as the number of potential information requests, thereby minimizing the adaptive challenge at the risk of violating the directive (Knill and Lenschow, 1998). Such patterns of institutionally bounded and persistence-driven implementation equally apply to many other Member States (Kimber, 2000) and other policies (Eichener, 1996; Duina, 1997).

Nevertheless, there are cases which seem to contradict our theoretical expectations. Consider, for instance, the implementation of varying environmental policies in Britain which went hand-in-hand with far-reaching reforms of regulatory styles and structures (Knill, 2001). In these cases, adjustment constituted a process dominated by political interests, with the bureaucracy playing an instrumental rather than autonomous role. The strong politicization of institutional adjustment is traceable to a rather exceptional situation in the UK, namely the general overhaul of British administrative structures initiated by the Thatcher government from the early 1980s onwards. Fundamental changes in regulatory practices in the context of implementing certain environmental directives was due primarily to general national reform developments rather than European adjustment requirements and therefore constitute no contradiction to our theoretical argument. The fact that British implementation of EU policies that were not related to these broader reform developments reflects the pattern of minimalist and persistence-driven adaptation (see, e.g., the EIA case above) underlines this point.

Degree of Change and Cross-national Convergence. The pattern of institutional persistence characterizing the implementation of coercive EU measures is particularly pronounced if these are in contradiction with deeply entrenched national administrative traditions. In other words, domestic resistance increases with the adaptive pressures emerging from European legislation. As a consequence, institutional changes are generally restricted to incremental and piecemeal adjustments (Knill, 2001; Knill and Lenschow, 1998). It follows that the continuation of existing institutional differences across countries rather than convergence of national arrangements characterizes fields of coercive EU governance such as the bulk of environmental policy. 


\section{The Competitive Impact of EU Governance: Road Haulage}

EU governance based on the promotion of competition between national institutions can be found in particular in market-making policies of the EU. These policies essentially exclude certain options from the range of national policy choices, rather than positively prescribing distinctive institutional models to be enacted domestically. They aim at the abolition of those domestic administrative arrangements that distort the functioning of the common market, such as national regulations protecting domestic industrial sectors against foreign competition.

The Competitive Nature of Road Haulage Policy. The impact of negative integration on the competition between national institutions can be illustrated by the case of road haulage. The project to establish a single transport market throughout the Community has made significant progress since the mid-1980s with the most crucial issue being the introduction of cabotage - the operation of non-resident hauliers in foreign domestic markets - in 1993.

European road haulage policy moved toward a deregulated international market by establishing a legal framework for removing the protection of national transport markets with resident operators. Apart from these restrictions, however, European legislation left Member States broad discretion in the design of a domestic framework for market regulation, for instance in the form of quantitative restrictions and price controls. In opening up domestic markets to international competition, however, the liberalization of cabotage implied fundamental challenges to established regulatory arrangements in the Member States. First, cabotage induced international regulatory competition in creating new strategic options for certain groups of actors such as users of transport services (as companies can decide freely whether they have their goods transported by foreign or domestic hauliers), while reducing the number of feasible options for others (e.g. in the light of European competition, domestic tariff regimes for road transport are no longer sufficient to promote the market position of national hauliers). International regulatory competition, in turn, put pressure on the Member States to redesign domestic market regulations in ways to replace regulatory burdens on domestic industries restricting their competitiveness.

Rationality of Institutional Change. The regulatory reforms that took place in the Member States in response to European road haulage policies indicate that the effective achievement of certain political outcomes and impacts (performance), rather than the objective of preserving existing arrangements (persistence), can drive the process of institutional adjustment under certain conditions. The central focus in the Member States was the promotion of the 
international competitiveness of the national haulage industry and thus, the redesign of existing regulatory arrangements in such a way as to avoid competitive disadvantages for the industry. In addition to this general objective, Member States pursued various additional goals, depending on dominant policy paradigms and existing interest and power constellations at the national level (Héritier et al., 2001).

While institutional performance, and here in particular international competitiveness, were the main forces driving national regulatory reforms, bureaucratic interests in conserving existing arrangements were hardly of any influence in this process. The bureaucracy served as an instrument to implement domestic political decisions and contributed to far-reaching regulatory reforms in most of the countries under investigation. More concretely, in Germany and Italy the abolition of the highly interventionist regulation in favour of a liberal approach constituted a fundamental departure from existing patterns. Notwithstanding certain regulatory differences, their original haulage policies shared important characteristics: the regulation of market access by quantitative licensing restrictions and the regulation of market operation by a differentiated system of maximum and minimum rate levels. Although the objectives initially associated with the interventionist approach, namely the protection of railway freight transport and the provision of an efficient transport system, had never been achieved in Germany or Italy, regulatory failures had caused no departures from the established approach prior to EU policy. In response to European liberalization, however, both countries engaged in fundamental reforms. In Germany these developments took place early with the elimination of price controls, licensing schemes and the closure of main agencies (Teutsch, 2001). In Italy the administration initially tried to preserve existing regulatory arrangements, which were characterized by a clientelistic relationship between regulatory authorities and the haulage industry, and even increased its interventionist approach in order to protect the domestic market. Piecemeal adjustments to the regulatory framework merely hid subsidies to national hauliers. However, this persistence-driven practice was not only sanctioned by several decisions of the European Court of Justice, but also increasingly challenged by growing competition from the European market. It failed to achieve its central political objectives, namely to promote the international competitiveness of the Italian industry. As a consequence, in the late 1990s the interventionist approach was completely abolished in favour of a liberalized regime (Kerwer, 2001). As revealed by the Italian case, regulatory competition beat even strong bureaucratic attempts to secure institutional structures and triggered the adoption of a performance-driven logic of regulatory adjustment.

In France and the Netherlands the domestic regime was already close to the liberal market model, and yet the prospect of increased competition gave 
rise to structural reforms. In France political pressure built up to introduce new forms of social regulation with respect to working hours and minimum prices, albeit without questioning the dominant liberal approach. In the Netherlands a distinctive approach to domestic haulage regulation, combining a liberalized transport market with active industrial policy, was instituted to promote the competitiveness of the domestic industry through public-private partnerships (Lehmkuhl, 2001).

Degree of Change and Cross-national Convergence. The performance-driven pattern of national institutional change carries a higher potential for fundamental reforms, clearly exceeding the scope of incremental administrative self-adaptation. This expectation was confirmed by the comparative study by Héritier et al. (2001). As described above, this was most apparent in Germany and Italy where both countries completely eliminated existing restrictions on market access (licensing schemes) and market operation (price control or bracket tariffs); in addition, agencies responsible for the enforcement and implementation of these tasks were completely abolished. Substantive, albeit less dramatic, regulatory changes took place in France and the Netherlands as both countries had already liberalized their haulage markets before the adoption of corresponding EU legislation. Nevertheless, considerable institutional adjustments were made in response to increased competitive pressure in the form of a regime of social regulation (France) and public-private partnerships (the Netherlands). Only in Britain did EU policies trigger few adjustments to an already highly liberalized regulatory framework.

With respect to convergence of national regulatory styles and structures in the transport sector, we find mixed evidence. On the one hand, we see strong convergence towards liberalized frameworks of market regulation in all countries under investigation. On the other hand, there remain important differences between countries with respect to complementary regulatory elements. While Britain, Germany and - somewhat delayed - also Italy have established a purely liberalized regime, France and the Netherlands introduced additional elements which represent departures from pure liberalization. These findings show that EU-induced competition between national institutions indeed favours increased, albeit not full convergence of regulatory arrangements. Remaining national differences can be traced to a variety of factors, ranging from sectoral regulatory traditions to reform capacities and forms of politicization.

\section{The Communicative Impact: Environmental and Social Policies}

Governance based on communication and information exchange between national policy elites is both a very old and a very modern approach to coordinating policy-making of sovereign nation-states in the light of transnational 
problems (e.g. transboundary environmental pollution) or shared policy objectives (e.g. securing social cohesion). The low key interventionist nature of this approach has much to do with widespread resistance of national policy-makers to giving up competences to organizations 'above' the nation-state. Nevertheless, a layer of supranational governance surfaced early on in response to certain co-ordination needs. The Organization of Economic Cooperation and Development (OECD), in particular, emerged as an important setting for policy experts and national policy elites to exchange views on mutual policy problems and concerns. Especially in economically relevant questions it served as a forum for cross-national 'peer review' triggering the diffusion of policy concepts among its members. While the EU is part of this communication network, it is also increasingly adopting this form of governance internally. As part of the 'new governance' agenda, the dialogue between national administrations rather than coercion is gaining relevance, especially in those policy areas where the EU has few regulatory competences.

The Communicative Nature of Environmental and Social Policies in the OECD and the $E U$. Before elaborating on this rationality of change and its institutional consequences, we will introduce some empirical evidence illustrating this communicative mode of governance in both the OECD and the EU. The OECD has been identified as instrumental in the diffusion of environmental policy concepts, approaches and structures across its members due to three mechanisms which we subsume under the label of communicative governance: The OECD offers the infrastructure for multilateral communication; it garners expert knowledge and promotes distinctive policy approaches. For this purpose it has built up an extensive infrastructure to facilitate the meeting of national policy-makers and their pursuit of a general environmental strategy (see the OECD website). The operational work is done in working parties, more narrow working groups, expert groups and task forces, as well as joint settings to co-ordinate the work with other OECD committees and bodies. Based on this extensive and dynamic institutional framework, the OECD was capable of giving decisive impetus to the rather rapid setting up of environmental ministries in most industrialized countries since the 1970s (Jörgens, 1996), reflecting not only new political priorities and associated attempts at capacity- building (Jänicke and Weidner, 1997), but also the desire to legitimate national representatives in these organizational settings.

Based on a reputation of providing 'sound knowledge', but also due to its credibility as an economic development organization safeguarding against 'green dogma', the OECD has been able to play a crucial role in promoting certain environmental policy principles - such as the polluter pays or the environmental integration principle - and the concept of sustainable development 
as the overarching framework for national and global policy. Most notably, the OECD can be considered a main promoter of economic instruments such as taxes, charges and tradeable permits to ensure the integration of environmental policies into sectoral policies. Indeed, these instruments are diffusing rapidly among OECD member countries, despite widespread resistance to the adoption of such instruments at the EU level.

The institutional implications of these concepts and instruments are enormous: the application of the environmental policy integration principle involves the strengthening of horizontal co-ordination (and control) between the environment and relevant sectoral ministries or administrative units and is likely to intrude into established patterns of administrative interest intermediation - especially in the case of clientelistic relationships between bureaucracy and private actors (Jordan, 2002; Müller, 2002). The shift towards taxes and incentive systems implies an administrative 'paradigm shift' in those countries where a legalistic, top-down interventionist regulatory style dominates; it bears the potential of leading to the overhaul of procedures and probably also of staff.

The mechanism behind this cross-national policy transfer and institutional change has been coined 'learning through performance comparison' (Tews, 2002 , p. 174). In publishing country surveys and environmental performance reviews, the OECD has institutionalized a system of peer review and constructed implicit league tables ranking national policies according to previously agreed criteria. Regular reports identifying best practice models provide further guidance to national policy-makers, paving the way for diffusion. In the environmental field these OECD-induced cross-national communications go hand-in-hand with OECD expert advice and aim at ensuring national responsiveness to innovative ideas and models. Studies have shown that Member States do take 'their' performance reviews and the supply of best practices models very seriously (Kern et al., 1999, p. 6) and follow up with necessary policy and institutional adaptations.

In recent years, the EU has added a similar mode of governance to its repertoire. Of course, it can be argued that policy formulation especially inside the European Commission always relied on an open dialogue with and between representatives of national administrations as well as policy experts with an impact on national administrative discourses and structures (Egeberg et al., 2003). But, here we want to focus on a 'new' form of regulatory policymaking: the open method of co-ordination (OMC).

In short, the OMC implies:

- fixing guidelines for the Union and specific timetables for achieving set goals in the Member States;

- establishing indicators and benchmarks as a means of comparing best practice; 
- translating the European guidelines into national policy reform actions which are integrated into national action plans (NAPs); and

- periodic monitoring, evaluation and peer review, organized as mutual learning processes (European Council, 2000).

At present the OMC is applied to domains like the information society, research and development, enterprises, economic reforms, education, employment, social inclusion, health care and pensions - i.e. flanking policies for building the economic union with an emphasis on social cohesion. The concrete design of the OMC varies from policy field to policy field, some emphasizing information exchange (e.g. pensions and health), others building up stronger adaptation pressure through cross-national and Commission peer reviews (e.g. employment and, to a lesser extent, also social inclusion).

Although couched in the rhetoric of subsidiarity, this mode of governance aims at moving national administrations out of a persistence-driven into a responsive mode of behaviour. The obligation to develop national action plans and engage in regular reporting compels national administrations to adjust intra- and interdepartmental procedures to this task. Furthermore, cross-national peer review requires national administrations to justify organizational structures and work methods as being capable of meeting the agreed guidelines and - maybe even more importantly - as communicable and attractive to peers. Hence, although the OMC process was devised to respect national institutional arrangements while inciting Member States to pursue certain commonly defined objectives, some authors see a chance (some would argue the risk) that exemplary performers in achieving the benchmarks become identified as model-givers to be copied, eventually reducing diversity (Lundvall and Tomlison, 2001). Also, the benchmarks themselves may be associated with certain policy paradigms requiring a 'discontinuous jump towards new ways of organizing knowledge' (Radaelli, 2000, p. 2, cited in de la Porte, 2002, p. 43) and adjusting institutional structures. For instance, the focus in the EU employment strategy on the employment rate of women or active labour market policies does imply paradigmatic challenges to Member States of the corporatist and southern welfare state types which follow the male breadwinner-female carer model and traditionally emphasize the social protection of workers over the encouragement of employment growth. Similarly, before the OMC agreement not all countries had a central policy on social inclusion. Italy for instance, had no structured activity in this area; other countries had relied on the decentralized management of such programmes (Peña Casas, 2002; de la Porte, 2001, both cited in de la Porte, 2002). ${ }^{2}$

2 Of course, the OMC is not the only factor leading countries to rethink traditional social policy (EspingAndersen, 1997; Leibfried and Rieger, 2003) and the institutional dynamic is not the same in all policy fields but depends on the depth of the OMC guidelines and the extent of peer review. 
Rationality of Institutional Change. Communicative governance relies on the normative power of leading ideas and concepts. In Drezner's words, 'states alter institutions and regulations because a set of beliefs has developed sufficient normative power that leaders fear looking like laggards if they do not adopt similar policies' (2001, p. 57; emphasis added) or models. Mere exchange of information and ideas will serve to develop a full 'story' around new concepts, forming coherent arguments for its adoption and concrete advice on practical implementation; however, the 'exercise of shaming' (Botcheva and Martin, 2001, p. 15) implied in peer reviews and league tables combined with the exercise of praising, as institutionalized in best practice models, taps some competitive spirit in national actors as well as the real need to legitimize national structures and approaches in a cross-national comparative discourse. This discourse includes not only representatives of national executives and administrations, but also stakeholders in society who may utilize comparative evidence to create 'bottom up' pressure for structural reform.

Deliberation rather than coercion or competition, learning rather than blockage or competitive racing, those are the contrasting key words distinguishing this mode of governance from those discussed above. But here as well, there is some evidence that Member States attempt persistence or window-dressing strategies to protect existing institutional arrangements. Some initial reactions to the EU OMC strategies point in this direction (see Chalmers and Lodge, 2003, for a generally critical assessment). In the case of social inclusion, de la Porte quotes studies observing that Denmark explicitly chose to maintain the national thrust of its programmes (2001, pp. 74-5) which corresponded widely, however, to the EU framework. Italy, while appearing to adopt the European framework, failed to integrate it into existing policy processes (de la Porte, 2002, p. 54) and minimized the institutional reform effort by merely patching up existing structures.

But given the process character of this mode, exposing national political and administrative actors regularly to monitoring and review, evidence of progress and reform, and hence dynamism rather than sole compliance with a given standard or norm, become the core for legitimating national institutions and procedures over time. Especially as long as 'best practice' is still an open category - as is the case in most EU OMC areas - countries are judged on the basis of meeting certain benchmarks as well as on their 'experimentation' with new governance forms and willingness to engage in reforms generally. The Commission's first-generation 'league tables' present evidence of that (see, e.g., Commission 2002). Longer-term data on environmental reforms triggered by OMC-like processes within the OECD underline the fact that communicative governance can induce a dynamic rationality of national actors, leading them to overcome the first 'reflex' of persistence. Institutional experimentation in 
the medium term entered into a dominant stream, with countries copying the models of trendsetters and opinion leaders (Kern et al., 1999). Institutional legitimacy became linked to fitting into an emerging transnational norm, of course with the consequence that institutional dynamism decreases once this norm is met.

Communicative governance also has a competitive component and is not 'innocently' framing information exchanges and learning processes. In contrast to competitive governance, however, competition here focuses on form at least as much as performance. Especially in the advanced stages of communicative governance, once policy ideas and best practice models have become established as standard, responsive bureaucracies seeking legitimization within this discourse may lose sight of locally more fitting and effective alternatives. The history of the OMC is too short, however, to analyse the validity of this risk and we are not aware of any studies dealing with relevant evidence from the OECD.

Degree of Change and Cross-National Convergence. The brief history of the OMC does not permit a final conclusion to our hypotheses which expect a moderate degree of institutional change and potentially strong cross-national convergence associated with the communicative style of governance. The convergence hypothesis is stronger at least than the rhetoric surrounding the OMC, which explicitly denies that Member States should converge to the same model but merely hopes that Member States converge at the level of outcomes (benchmarks). Nevertheless, beginning with the level of 'rhetoric convergence' (Hay, 2002, p. 11), we suggest that the search for transnational legitimization on the part of national policy elites pushes them towards copying highly reputed models. In policy fields with structurally very distinct families, learning or mimicking may take place primarily within such a circle (see Scharpf, 2002, on social policy and families of welfare state). Reflecting on the most developed European employment strategy, de la Porte (2002) observes clear evidence of general rhetorical convergence, with all Member States committed to common guidelines, although these pose very different ideological and institutional challenges on the various welfare families. Actual institutional change so far is structured by welfare state types, with members of the most 'challenged' types still resisting true reform as we would expect given the initial persistence 'reflex'.

More conclusive OECD evidence, in turn, is clearly supportive of our hypothesis. Researchers at the Forschungsstelle für Umwelt at the Free University of Berlin have engaged in extensive studies showing the degree of international diffusion of environmental policy innovation and institutional convergence, pointing to the spread of environment ministries, national environment plans, 
economic instruments, changing administrative structures, regulatory style and even state-society relations. After about 30 years of environmental policymaking, the degree of change as well as convergence has been enormous. Kern (2000) argues that once a critical mass of countries adopting certain institutional models was reached, other countries rapidly jumped on the bandwagon, leading to diffusion especially among industrialized states with only a few late-comers joining after the early 1980s. This 'story' benefits of course from the general absence of deeply institutionalized - and persistent - models of environmental governance in most states prior to the 1970s. The already observable responsiveness at the rhetorical level, and in view of a widely acknowledged crisis of most welfare states suggests, however, that even in the social policy OMC cases we may be approaching a threshold of change. If this is the case, then some convergence - at least within welfare state families - seems more than plausible given the deliberative context created in the EU.

\section{Conclusion}

In recent years, a growing body of literature has been concerned with the emergence and development of new patterns of European governance and their impact on institutions, political processes and policies in the Member States. Our analysis contributes to this debate and suggests several general conclusions.

First, governance in the EU can hardly be understood on the basis of a general model, such as network governance (Kohler-Koch, 1999) or the 'regulatory state' (Majone, 1996). Rather, governance in the EU is characterized by a variety of different approaches. To grasp this variation, we analytically distinguish between three sources of national institutional change. EU regulatory policy may trigger national adjustments either through legal coercion, the promotion of competition between national institutions or the stimulation of communication and information exchange in transnational networks.

Second, each of these ideal-typical modes of governance has different effects on the process and outcome of national institutional change. We identify three underlying rationalities - persistence-driven, outcomes-driven and legitimacy-driven - driving domestic processes of adjustment. These behavioural logics guiding administrative adaptation have varying effects with respect to the degree of potential change and the likelihood of convergence of national institutions. Interestingly, in this context there seems to be an inverse relationship between the political objective of harmonization and actual convergence. Coercive policies, which aim explicitly at harmonizing national policies, have a less pronounced drive towards convergence of domestic institutions than 
competitive and communicative governance approaches which, however, appear to bow to national diversity.

Third, the empirical section especially suggests that the processes of national institutional change are dynamic in character. Initially, we tend to encounter the persistence-oriented desire of national bureaucracies to preserve existing arrangements against pressures emanating from European policy. This orientation typically remains the dominant pattern if EU governance is based on a coercive approach. If, however, governance is based on competition or communication, other rationalities become increasingly influential over time and eventually dominate over initial resistance and, consequently, both the degree of institutional change and cross-national convergence may increase significantly.

Looking to the future, we emphasize that our distinction of different governance approaches and corresponding patterns of national institutional change is analytical rather than empirical. While the existence of 'hybrids' in the real world does not call our general argument into question, it hints at the need for careful analysis of the real complexities behind these general patterns in order to understand fully the domestic impact of a certain policy.

Correspondence:

Christoph Knill

Institut für Politikwissenschaft

Friedrich Schiller Universität Jena

Ernst Abbe Platz 8

D-07743 Jena, Germany

email: christoph.knill@uni-jena.de

\author{
Andrea Lenschow \\ Fachbereich für Sozialwissenschaften \\ University of Osnabrück \\ Seminarstrasse 23 \\ D-049069 Osnabrück, Germany \\ email: andrea.lenschow@uos.de
}

\section{References}

Bache, I. and Flinders, M. (eds) (2004) Multi-level Governance (Oxford: Oxford University Press).

Bennett, C. (1991) 'What is Policy Convergence and what Causes it?'. British Journal of Political Science, Vol. 21, No. 2, pp. 215-33.

Botcheva, L. and Martin, L.L. (2001) 'Institutional Effects on State Behavior. Convergence and Divergence'. International Studies Quarterly, Vol. 45, pp. 1-26.

Chalmers, D. and Lodge, M. (2003) 'The Open Method of Co-ordination and the European Welfare State'. Discussion Paper No. 11, ESRC Centre for Analysis of Risk and Regulation, London School of Economics and Politics.

Chiti, E. (2002) 'Decentralised Integration as a New Model of Joint Exercise of Community Funcitions? A Legal Analysis of European Agencies'. Arena Working Paper WP 02/3 (Oslo: Arena). 
Commission of the European Communities (2002) Joint Employment Report. Available at «http://www.europa.eu.int/comm/employment_social/employment_strategy/ report_2002/jer2002_final_en.pdf», Brussels.

Cowles, M.G. and Risse, T. (2001) 'Europeanization and Domestic Change: Conclusions'. In Caporaso, J., Cowles, M.G. and Risse, T. (eds) Europeanization and Domestic Change?.

Dehousse, R. (1997) 'Regulation by Networks in the European Community: The Role of European Agencies'. Journal of European Public Policy, Vol. 4, No. 2, pp. 246-61.

De la Porte, C. (2001) 'The Complex Soft Governance Technique and the Brittle Consensus in European Social Protection'. In Gabaglio, E. and Hoffmann, R. (eds) European Trade Union Yearbook 2000 (Brussels: European Trade Union Institute).

De la Porte, C. (2002) 'Is the Method of Co-ordination Appropriate for Organising Activities at European Level in Sensitive Policy Areas?'. European Law Journal, Vol. 8, No. 1, pp. 38-58.

DiMaggio, P.J. and Powell, W.W. (1991) 'The Iron Cage Revisited. Institutionalized Isophormism and Collective Rationality in Organizational Fields'. In Di Maggio P.J. and Powell, W.W. (eds) The New Institutionalism in Organizational Analysis, (Chicago: Chicago University Press).

Dolowitz, D.P. and Marsh, D. (2000) 'Learning from Abroad: The Role of Policy Transfer in Contemporary Policy-making'. Governance: An International Journal of Policy and Administration, Vol. 13, pp. 5-24.

Drezner, D.W. (2001) 'Globalization and Policy Convergence'. International Studies Review, Vol. 3, No. 1, pp. 53-78.

Duina, F. (1997) 'Explaining Legal Implementation in the European Union'. International Journal of the Sociology of Law, Vol. 25, pp. 155-79.

Egeberg, M., Schaefer, G.H. and Trondal, J. (2003) 'The Many Faces of EU Committee Governance'. West European Politics, Vol. 26, No. 3, pp. 19-40.

Eichener, V. (1996) 'Die Rückwirkungen der europäischen Integration auf nationale Politikmuster'. In Jachtenfuchs, M. and Kohler-Koch, B. (eds) Europäische Integration (Leverkusen: Leske \& Budrich).

Esping-Andersen, G. (1997) Welfare States in Transition (? : Sage).

Flinders, M. (2004) 'Distributed Public Governance in the European Union'. Journal of European Public Policy, Vol. 11, No. 3, pp. 520-44.

Hay, C. (2002) 'Common Trajectories, Variable Paces, Divergent Outcomes? Models of European Capitalism Under Conditions of Complex Economic Interdependence'. Paper presented at the Biannual Conference of Europeanists, Palmer House Hilton, Chicago, 14-16 March.

Héritier, A., Knill, C., Kerwer, D., Lehmkuhl, D., Teutsch, M. and Douillet, A.C. (eds) (2001) Differential Europe. New Opportunities and Restrictions for Member-State Policies (Lanham: Rowman and Littlefield).

Holzinger, K. and Knill, C. (2004) 'Regulatory Competition and Regulatory Cooperation in Environmental Policy: Individual and Interaction Effects'. Journal of Public Policy, Vol. 25, No. 1, pp. ?. 
Jänicke, M. and Weidner, H. (eds) (1997) National Environmental Policies. A Comparative Study of Capacity-Building (Berlin: Springer).

Jordan, A. (2002) 'Efficient Hardware and Light Green Software: Environmental Policy Integration in the UK'. In Lenschow, A. (ed.) Environmental Policy Integration - Greening Sectoral Policies in Europe (London: Earthscan).

Jörgens, H. (1996) 'Die Institutionalisierung von Umweltpolitik im internationalen Vergleich'. In Jänicke, M. (ed.) Umweltpolitik der Industrieländer. Entwicklung - Bilanz - Erfolgsbedingungen (Berlin: Edition Sigma).

Kern, K. (2000) Die Diffusion von Politikinnovationen. Umweltpolitische Innovationen im Mehrebenensystem der USA (Opladen: Leske + Budrich).

Kern, K., Jörgens, H. and Jänicke, M. (1999) Die Diffusion umweltpolitischer Innovationen. Ein Beitrag zur Globalisierung von Umweltpolitik, FFU-Report 99-11, available at «http://www.fu-berlin.de/ffu/Publikationen/index.htm».

Kerwer, D. (2001) 'Going through the Motions: The Modest Impact of Europe on Italian Transport Policy'. In Héritier, A. et al. (eds) Differential Europe. New Opportunities and Restrictions for Member-State Policies (Lanham: Rowman and Littlefield).

Kimber, C. (2000) 'Implementing European Environmental Policy and the Directive on Access to Environmental Information'. In Knill, C. and Lenschow, A. (eds) Implementing EU Environmental Policy. New Directions and Old Problems (Manchester: Manchester University Press).

Knight, J. (1992) Institutions and Social Conflict (Cambridge: Cambridge University Press).

Knill, C. (2001) The Europeanization of National Administrations. Patterns of Institutional Change and Persistence (Cambridge: Cambridge University Press).

Knill, C. and Lehmkuhl, D. (2002) 'The National Impact of European Union Regulatory Policy: Three Europeanization Mechanisms'. European Journal of Political Research, Vol. 41, pp. 255-80.

Knill, C. and Lenschow, A. (1998) 'Coping with Europe: The Impact of British and German Administrations on the Implementation of EU Environmental Policy'. Journal of European Public Policy, Vol. 5, No. 4, pp. 595-14.

Kohler-Koch, B. (1999) 'The Evolution and Transformation of European Governance'. In Kohler-Koch, B. and Eising, R. (eds) The Transformation of Governance in the European Union (London: Routledge).

Lehmkuhl, D. (2001) 'From Regulation to Stimulation. The Reform of Dutch Transport Policy'. In Héritier, A. et al. (eds) Differential Europe. New Opportunities and Restrictions for Member-State Policies (Lanham: Rowman and Littlefield).

Leibfried, S. and Rieger, E. (2003) Limits to Globalization. Welfare States and the World Economy (Cambridge: Polity).

Lundvall, B.-A. and Tomlinson, M. (2001) 'International Benchmarking as a Policy Learning Tool'. In Rodrigues, M. et al. (eds) The New Knowledge Economy in Europe - A Strategy for International Competitiveness and Social Cohesion (? : Edward Elgar).

Majone, G. (1996) Regulating Europe: Problems and Prospects (London: Routledge). 
March, J.G. and Olson, J.P. (1989) The New Institutionalism: Organizational Factors in Political Life (New York: Free Press).

Marks, G., Hooghe, L. and Blank, K. (1996) 'European Integration from the 1980s: State Centric v. Multi-level Governance'. Journal of Common Market Studies, Vol. 34, No. 3, pp. 341-79.

Meyer, J.W. and Rowan, B. (1977) 'Institutionalized Organizations. Formal Structure as Myth and Ceremony'. American Journal of Sociology, Vol. 83, pp. 340-63.

Meyer, J.W., Frank, D.J., Hironaka, A., Schofer, E. and Tuma, N.B. (1997) 'The Structuring of a World Environmental Regime, 1870-1990'. International Organization, Vol. 51, No. 4, pp. 623-51.

Müller, E. (2002) 'Environmental Policy Integration as a Political Principle: The German Case and the Implications of European Policy'. In Lenschow, A. (ed.) Environmental Policy Integration - Greening Sectoral Policies in Europe (London: Earthscan).

Oates, W.E. and Schwab, R.M. (1988) 'Economic Competition Among Jurisdictions. Efficiency Enhancing or Distortion Inducing?'. Journal of Public Economics, Vol. 35, pp. 333-54.

OECD, available at «http://www.oecd.org/about/0,2337,en_2649_33713_1_1_1_1_ 1,00.html» (Paris: Organization for Economic Co-operation and Development).

Peña-Casas, R. (2002) 'Lutte contre la pauvreté et l'exclusion sociale : le premier cycle est accompli'. In Degryse, C. and Pochet, P. (eds) Social Developments in the European Union - 2001 (Brussels: European Trade Union Institute/Observatoire social européen).

Radaelli, C.M. (2000) 'Policy Transfer in the European Union'. Governance, Vol. 13, No.1, pp. 25-43.

Ragaglia, E. (2001) 'European Co-ordination of Social Inclusion Policies? The Danish and Italian Responses to the Lisbon Strategy'. MSc dissertation, Socrates Programme of The European Community, Università degli Studi di Pavia.de

Rose, R. (1991) 'What is Lesson-Drawing?'. Journal of Public Policy, Vol. 11, pp. 3-30.

Scharpf, F.W. (1999) Governing in Europe. Effective and Democratic (Oxford: Oxford University Press).

Scharpf, F.W. (2002) 'The European Social Model' . Journal of Common Market Studies, Vol. 40, No. 4, pp. 645-70.

Teutsch, M. (2001) 'Regulatory Reforms in the German Transport Sector: How to Overcome Multiple Veto Points'. In Héritier, A. et al. (eds) Differential Europe. New Opportunities and Restrictions for Member-State Policies (Lanham: Rowman and Littlefield).

Tews, K. (2002) Der Diffusionsansatz für die Vergleichende Policy-Analyse. Wurzeln und Potentiale eines Konzepts. Eine Literaturstudie. FFU-Report 2002-02, available at «http://www.fu-berlin.de/ffu/Publikationen/index.htm».

Winter, G. (1996) 'Freedom of Environmental Information'. In Winter, G. (ed.) European Environmental Law. A Comparative Perspective (Aldershot: London). 